\title{
NAIL MANIFESTATIONS IN PEMPHIGUS VULGARIS
}

\author{
Juliana Burihan Cahali, Everton Yuji Soyama Kakuda, Cláudia Giuli Santi and \\ Celina Wakisaka Maruta
}

RHCFAP/3098

CAHALI JB et al. - Nail manifestations in pemphigus vulgaris. Rev. Hosp. Clín. Fac. Med. S. Paulo 57(5):229-234, 2002.

Nail involvement in pemphigus vulgaris is rare. We describe 5 patients with pemphigus vulgaris presenting nail involvement. In this disease, nail manifestations present, by order of frequency, as chronic paronychia, onychomadesis, onycholysis, Beau's lines and trachyonychia. All our 5 cases presented with paronychia, and 1 of them also had Beau's lines. Treatment with prednisone and/or cyclophosphamide controlled mucocutaneous and nail manifestations in all cases.

DESCRIPTORS: Pemphigus vulgaris. Paronychia. Beau's lines. Prednisone. Cyclophosphamide.

\section{INTRODUCTION}

Pemphigus vulgaris is an autoimmune, mucocutaneous vesiculobullous disease ${ }^{1}$. It is characterized by intraepidermal bullae with suprabasal acantholysis and $\operatorname{IgG}$ autoantibody against a desmosomalassociated glycoprotein, desmoglein $1^{2,3}$. Although pemphigus vulgaris may occur at any age, its most common onset is in the fourth, fifth, and sixth dec$\operatorname{ades}^{4,5}$. Involvement of the nail in pemphigus vulgaris is rarely described. We describe 5 patients with chronic paronychia as a manifestation of pemphigus vulgaris.

\section{CASE REPORTS}

\section{Case 1}

A 65-year-old white woman presented in 1991 with oral erosions and cutaneous lesions on the whole body. Histological examination of the affected skin revealed suprabasal clefting containing acantholytic cells. Epidermal intercellular deposition of IgG was noted on direct immunofluorescence. After the diagnosis of pemphigus vulgaris, she was treated with $1 \mathrm{mg} / \mathrm{kg}$ daily of oral prednisone, which resulted in clinical resolution of both skin and oral mucosa lesions. In 1996, free of mucocutaneous lesions, on a daily maintenance dose of $10 \mathrm{mg} /$ day of prednisone, she developed erythema, edema, pustules, inflammation, and suppuration of the proximal and lateral nail folds of several fingernails and toenails associated with Beau's lines of the $2^{\text {nd }}, 3^{\text {rd }}$, and $4^{\text {th }}$ digits on the left hand (Fig. 1). Gram stain and potassium hydroxide preparations of nail drainage were negative. Bacterial and fungal cultures disclosed Staphylococcus aureus, but no fungi. Topical and oral antibiotic therapy produced no beneficial effect. A biopsy

From the Department of Dermatology, Hospital das Clínicas, Faculty of Medicine, University of Sao Paulo. specimen of the nail fold of the right first toe revealed suprabasal clefting and acantholysis. Direct immunofluorescence showed positive intercellular deposition of IgG and C3. Indirect immunofluorescence was positive at a dilution of 1/10240. Thus, we considered the paronychia to be a clinical manifestation of pemphigus vulgaris. Mucocutaneous lesions of pemphigus vulgaris occurred 2 weeks after the nail involvement. She was treated with a new cycle of prednisone $1 \mathrm{mg} / \mathrm{kg} /$ day, resulting in clinical resolution of mucocutaneous and nail lesions with no residual damage on the nails.

\section{Case 2}

A 15-year-old white man with pemphigus vulgaris diagnosed in 1993 presented initially with ulcerations in the oral cavity and simultaneous involvement of the nails. The latter was characterized by erythema, edema, inflammation, and bullae, with purulent drainage on $1^{\text {st }}$ and $4^{\text {th }}$ right fingers and $1^{\text {st }}$ and $2^{\text {nd }}$ left fingers (Fig. 
2). Skin lesions of pemphigus vulgaris appeared 1 month later. Histological examination of the affected skin revealed suprabasal clefting and acantholysis. Direct and indirect immunofluorescence of perilesional skin showed epidermal intercellular deposition of IgG and C3. Gram stain and potassium hydroxide preparations of the drainage were negative, as were bacterial and fungal cultures. Nail biopsy was not performed. He was treated with a $1 \mathrm{mg} / \mathrm{kg}$ daily dose of oral pred-

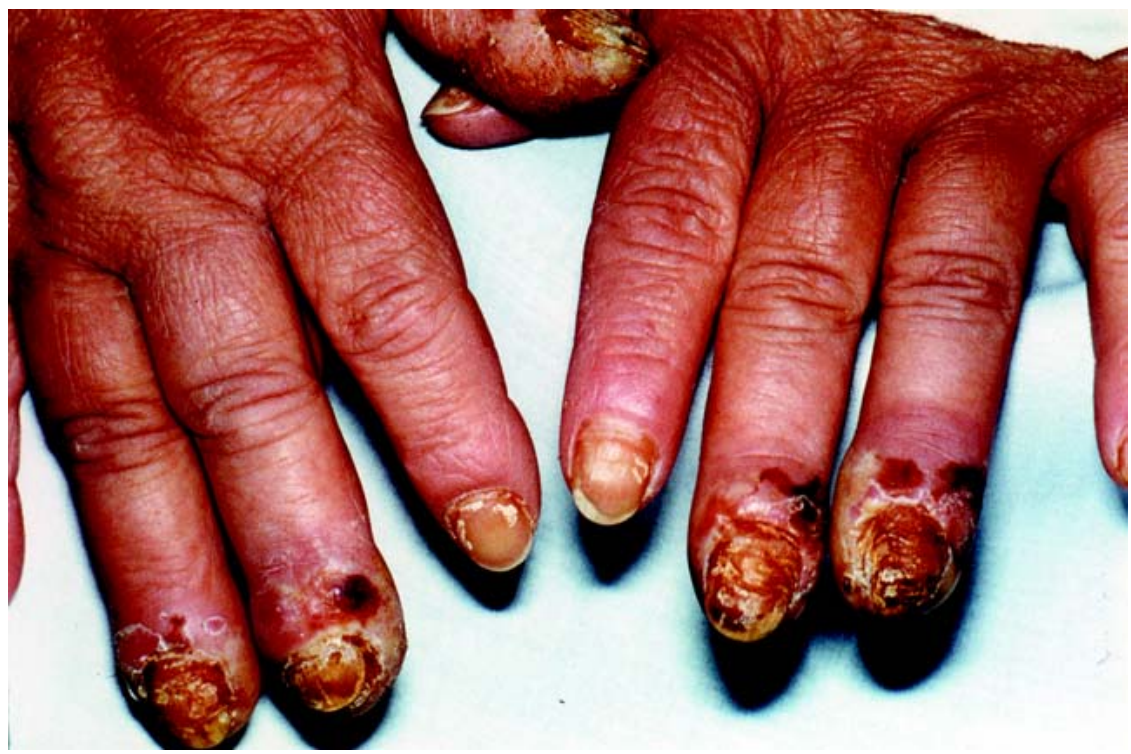

Figure 1 - CASE 1: Erythema, edema, pustules, and hemorrhagic crusts on the nail folds of her fingers. Beau's lines on $3^{\text {rd }}$ and $4^{\text {th }}$ left fingernails.

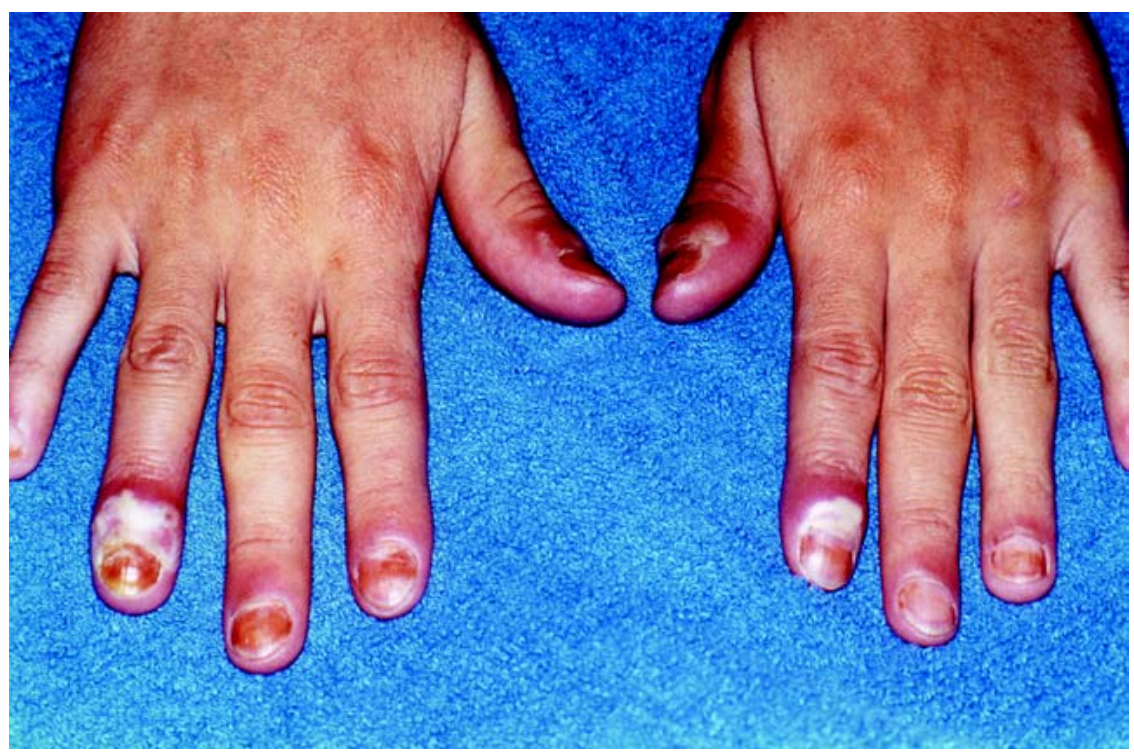

Figure 2 - CASE 2: Erythema, edema, and bullous lesions, with purulent drainage on $1^{\text {st }}$ and $4^{\text {th }}$ right fingernails and $1^{\text {st }}$ and $2^{\text {nd }}$ left fingernails.

nisone. Mucocutaneous and nail lesions improved simultaneously with this therapy, with no permanent damage on the nail.

\section{Case 3}

A 27-year-old white woman with pemphigus vulgaris diagnosed in $\mathrm{Au}-$ gust 2000 presented initially with skin lesions, oral erosions, and nail involvement characterized by erythema, edema, and purulent drainage from the

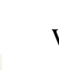

o..

A 44-year-old white woman with pemphigus vulgaris diagnosed in $\mathrm{Au}-$ gust 2000 presented initially with skin and oral lesions. Nail lesions occurred 3 months later, with erythema and edema on the lateral and posterior nail folds of her $1^{\text {st }}, 2^{\text {nd }}$, and $3^{\text {rd }}$ left and right fingers (Fig. 4). She noticed exacerbation of the mucocutaneous lesions 2 weeks after the development of the paronychia. She was diagnosed as having pemphigus vulgaris on the basis of a skin biopsy and direct immunofluorescence. Indirect immunofluorescence was positive at a dilution of $1 / 2560$. Nail biopsy was not performed. Gram stain and potassium hydroxide preparations of the nail were negative, as were bacterial and fungal cultures. Mucocutaneous and nail lesions improved with oral prednisone 1 $\mathrm{mg} / \mathrm{kg}$ daily associated with endovenous cyclophosphamide $(900 \mathrm{mg} /$ dose, monthly) and methylprednisone (300 mg/day during 3 consecutive days in the $2^{\text {nd }}$ month of the treatment).

\section{Case 5}

A 39-year-old white woman with pemphigus vulgaris diagnosed in 1990 presented initially with oral erosive lesions. Skin lesions appeared 2 months later. One month after that, the 


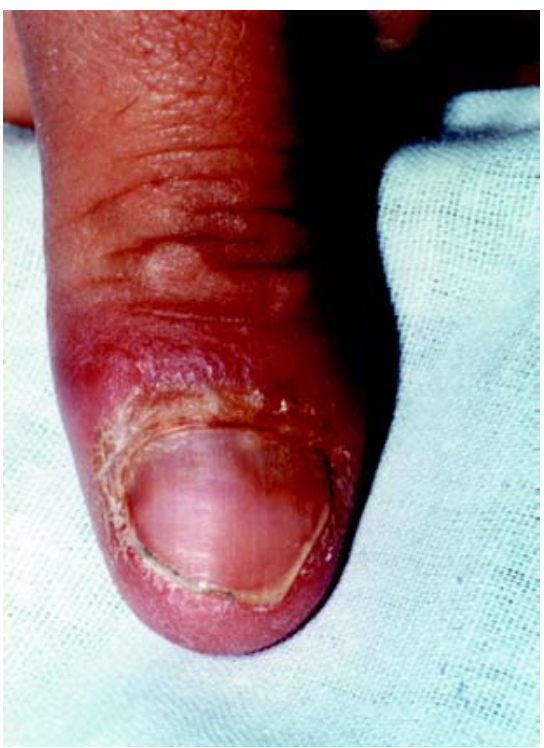

Figure 3 - CASE 3: Erythema, edema, and purulent drainage on the first right finger.

nail involvement began. It was characterized by erythema and edema on all 20 nails, with purulent drainage of her left and right first fingers. Nail involvement preceded an exacerbation of mucocutaneous disease. She was diagnosed as having pemphigus vulgaris on the basis of a skin biopsy and direct immunofluorescence. Nail biopsy was not performed. Gram stain and potassium hydroxide preparations were negative. Bacterial and fungal cultures disclosed Staphylococcus aureus, but no fungi. Oral antibiotic therapy produced no beneficial effect on the paronychia. Mucocutaneous lesions and



Figure 4 - CASE 4: Erythema and edema on the lateral and posterior nail folds of her $1^{\text {st }}, 2^{\text {nd }}$, and $3^{\text {rd }}$ left and right fingers, with purulent drainage.

paronychia improved markedly with oral prednisone $(1 \mathrm{mg} / \mathrm{kg}$ daily) and endovenous cyclophosphamide $(0.5 \mathrm{~g}$ to $1 \mathrm{~g} /$ dose, monthly).

\section{DISCUSSION}

Pemphigus vulgaris is an autoimmune, mucocutaneous vesiculobullous disease ${ }^{1,5}$. Nail disease has been reported in a variety of manifestations: chronic paronychia, Beau's lines, trachyonychia, onychomadesis, onycholysis, subungueal hemorrhage, nail plate discoloration, pitting, ony- choschizia, and nail dystrophy ${ }^{1,6-15}$. Engineer et al. ${ }^{1}$ summarized all reports in the English literature on nail involvement in patients with pemphigus vulgaris (15 patients). The most frequent alterations were paronychia $(60 \%)$ and onychomadesis (33\%). Our 5 patients had paronychia, and 1 of them had Beau's lines. According to the literature, fingernails were more often involved than toenails ( 9 had fingernails involved, 5 had finger and toenails involved, and 1 had only toenails involved). In our series, no one had toenail involvement alone (Table 1). In the previously reported cases in

Table 1 - Clinical and laboratory features of the patients.

\begin{tabular}{|c|c|c|c|c|c|}
\hline & PATIENT 1 & PATIENT 2 & PATIENT 3 & PATIENT 4 & PATIENT 5 \\
\hline sex/age & $\mathrm{F} / 65$ & $\mathrm{M} / 15$ & $F / 27$ & $\mathrm{~F} / 44$ & $\mathrm{~F} / 39$ \\
\hline nail lesion & $\begin{array}{l}\text { paronychia and } \\
\text { Beau's lines } \\
\text { finger and toenails }\end{array}$ & $\begin{array}{l}\text { paronychia } \\
\text { fingernails }\end{array}$ & $\begin{array}{l}\text { paronychia } \\
\text { fingernails }\end{array}$ & $\begin{array}{l}\text { paronychia } \\
\text { fingernails }\end{array}$ & $\begin{array}{l}\text { paronychia } \\
\text { finger and toenails }\end{array}$ \\
\hline Gram stain & negative & negative & negative & negative & negative \\
\hline Culture & S. aureus & no growth & no growth & no growth & S. aureus \\
\hline onset of paronychia & $\begin{array}{l}\text { before generalized } \\
\text { exacerbation }\end{array}$ & $\begin{array}{l}\text { part of initial } \\
\text { presentation }\end{array}$ & $\begin{array}{l}\text { part of initial } \\
\text { presentation }\end{array}$ & $\begin{array}{l}\text { before generalized } \\
\text { exacerbation }\end{array}$ & $\begin{array}{l}\text { before generalized } \\
\text { exacerbation }\end{array}$ \\
\hline $\begin{array}{l}\text { histology of } \\
\text { periungueal } \\
\text { disease }\end{array}$ & $\begin{array}{l}\text { suprabasal } \\
\text { clefting with } \\
\text { acantholysis }\end{array}$ & not done & not done & not done & not done \\
\hline $\begin{array}{l}\text { Direct } \\
\text { Immunofluorescence } \\
\text { of periungueal disease }\end{array}$ & $\begin{array}{l}\text { epidermal } \\
\text { intercellular } \\
\text { deposition of } \mathrm{IgG}\end{array}$ & not done & not done & not done & not done \\
\hline
\end{tabular}


the literature, the nail changes occurred independently of the extent of disease $(67 \%$ had mucocutaneous lesions, $27 \%$ had cutaneous lesions, and just $6 \%$ had only mucosal disease). All of our patients had mucocutaneous disease. Nail involvement is due to bullous lesions in the nail bed, nail matrix, or nailfold ${ }^{1}$ as part of the disease process ${ }^{8}$. Nail disease can be part of the initial presentation along with mucosal and cutaneous lesions (47\% of all cases reported), can precede a flare of the pre-existing disease (33\%), or can be the only sign of the disease $(20 \%)$. In our study, nail involvement preceded a flare of the disease in 3 cases and was part of the initial presentation in 2 cases (Figs. 5 and 6).
We thought bacteria and fungi were secondary invaders ${ }^{6}$ and the chronic paronychia would not be resolved with antibiotic or antifungal therapy. Another possibility that could be included among the differential diagnosis is herpetic whitlow, since these patients are chronically under the use of immunosuppressive drugs. This diagnosis could be ruled out once the paronychia was resolved with the proper pemphigus control. In our cases, nail biopsy was performed only in case 1 . In the others, we did not take biopsy specimens because the diagnosis of pemphigus vulgaris had already been made histologically and by direct and indirect immunofluorescence of the affected skin, and there is a known association of pemphigus vulgaris with nail disease.

\section{CONCLUSION}

We present 5 patients with pemphigus vulgaris and nail involvement. This involvement can be part of the initial presentation, precede a flare of the pre-existing disease, or can be the only sign of the disease.

It is important in patients with pemphigus vulgaris and paronychia to be aware that the nail changes can be a manifestation of the autoimmune disease, and in these cases, treatment directed against fungi, bacteria, and viruses may not be effective.

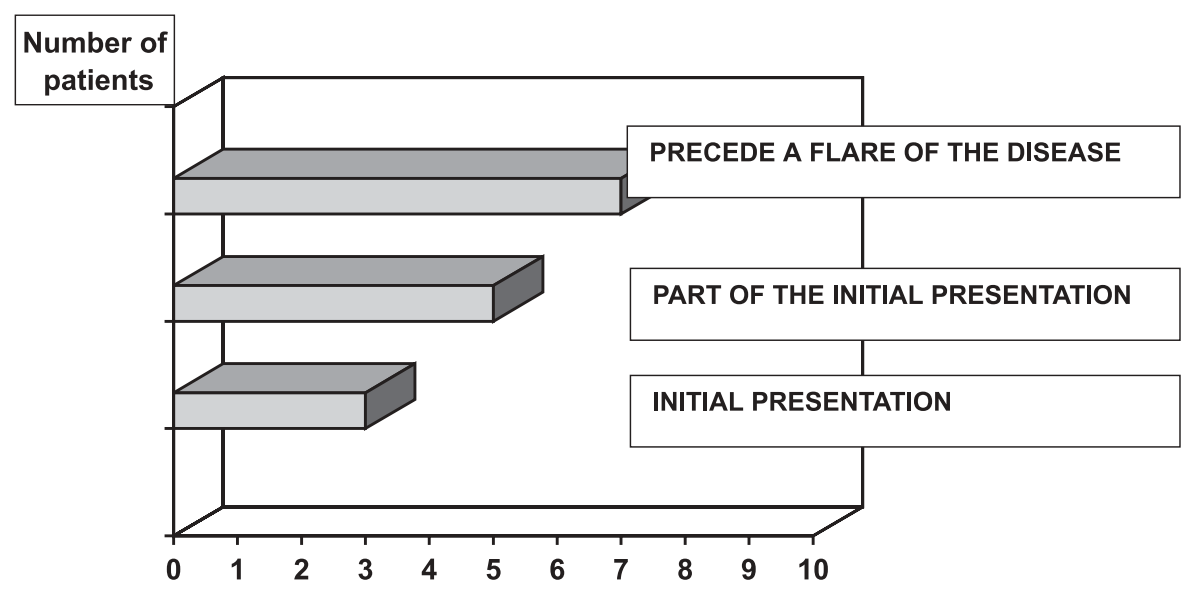

Figure 5 - Onset of nail disease, according to the literature.

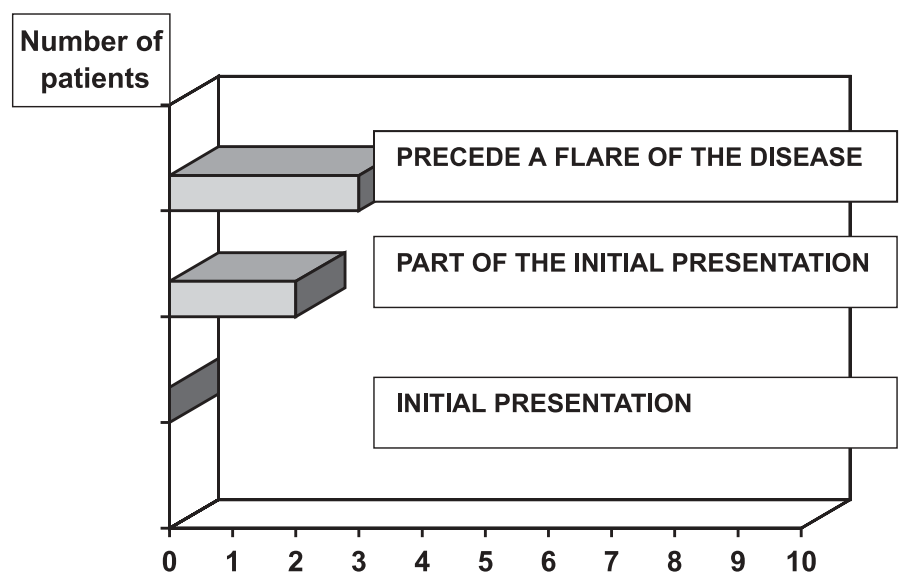

Figure 6 - Onset of nail disease in this series. 
CAHALI JB e col. - Manifestações ungueais no pênfigo vulgar. Rev. Hosp. Clín. Fac. Med. S. Paulo 57(5):229-234, 2002.

$O$ acometimento ungueal no pênfigo vulgar é um achado raro. Descrevemos cinco doentes com pênfigo vulgar e alterações ungueais. As alte- rações ungueais descritas no pênfigo vulgar são, em ordem decrescente de ocorrência: paroníquia crônica, onicomadese, onicólise, linhas de Beau e traqueoníquia. Paroníquia crônica foi a forma de acometimento ungueal encontrada em todos os doentes deste estudo e um deles apresentou, também, linhas de Beau. As ma- nifestações cutâneo-mucosas e ungueais foram controladas, em todos os casos, com o uso de prednisona e/ ou ciclofosfamida.

DESCRITORES: Pênfigo vulgar. Paroníquia. Linhas de Beau. Prednisona. Ciclofosfamida.

\section{REFERENCES}

1. ENGINEER L, NORTON LA \& AHMED R - Nail involvement in pemphigus vulgaris. J Am Acad Dermatol 2000; 43: 529-35.

2. CHAMPION RH, BURTON JL, BURNS DA et al. - Textbook of Dermatology. 6th ed. Oxford, Blackwell Science, 1998. p. 1849-1855.

3. EYRE RW \& STANLEY JR - Identification of pemphigus vulgaris antigen extracted from normal human epidermis and comparison with pemphigus foliaceus antigen. J Clin Invest 1988; 81: 807-12.

4. SAMPAIO SAP \& RIVITTI EA - Dermatologia. Brasil. 2th ed. São Paulo, Artes Médicas, 2000. p. 229-248.
5. MARTINS CR, SQUIQUERA HL \& DIAZ LA - Pemphigus vulgaris and pemphigus foliaceus. Curr Probl Dermatol 1989; 1: 3361.

6. KIM BS, SONG KY, YOUN JI et al. - Paronychia - A manifestation of pemphigus vulgaris. Clin Exp Dermatol 1996; 21: 315-7.

7. De BERKER D, DALZIEL K, DAWBER RPR et al. - Pemphigus associated with nail dystrophy. Br J Dermatol 1993; 129: 461-4.

8. PARAMESWARA YR \& NAIK RPC - Onychomadesis associated with pemphigus vulgaris. Arch Dermatol 1981; 117: 759-60. 
9. BAUMAL A \& ROBINSON M - Nail bed involvement in pemphigus vulgaris. Arch Dermatol 1973; 107 :751.

10.DHAWAN SS, ZAIAS N \& PENA J - The nail fold in pemphigus vulgaris. Arch Dermatol 1990; 126: 1374-5.

11.AKIYAMA C, SOU K, FURUYA T, SAITOH A el al. - Paronychia: a sign heralding an exacerbation of pemphigus vulgaris. J Am Acad Dermatol 1993; 29: 494-6.

12.RIVERA DIAZ R, LLAMAZARES JA, PERALTO JLR et al. - Nail involvement in pemphigus vulgaris. Int J Dermatol 1996; 35: 581-2.
13.FULTON RA, CAMPBELL I, CARLYLE D et al. - Nail bed immunofluorescence in pemphigus vulgaris. Acta Derm Venereol (Stockh) 1983; 63: 170-2.

14.LEROY D, LEBRUN J, MAILLARD V et al. - Pemphigus végétant a type clinique de dermatite pustuleuse chronique de hallopeau. Ann Dermatol Venereol 1982; 109: 549-55.

15.STONE OJ \& MULLINS JF - Vegetative lesions in pemphigus. Dermatol Int 1966; 5: 137-40.

Received for publication on February 25, 2002. 